E. J. JOSEY

\title{
The College Library in New York's 3R System
}

In an effort to determine the attitudes of academic librarians in New York State vis-à-vis the 3R's program, a questionnaire was distributed to forty such persons now involved in it. Replies indicate that: 1) the role of the college library in such a program differs from that of the public library; 2) they have benefited from the program in a variety of ways; and 3) they envision a range of cooperative efforts remaining to be attempted as funding becomes available.

\section{BIRTH OF THE 3R's}

$\mathrm{T}_{\mathrm{r}}$ HE REFERENCE and Research Library Resources Program, or the 3R's as the program is widely known, developed as a result of the critical need to supply advanced scholars in New York State immediate access to research library materials. Although the state's twenty-two public library systems were serving, generally, the reading and reference needs of 98 per cent of the population through more than seven hundred public libraries, nevertheless college students and college faculty, graduate students, scientists, industrial researchers, and writers were not assured ready access to the rich resources of the special and private research libraries where use was restricted only to a small segment of the research community.

Higher education in New York State began to grow at a rapid rate. Because of the rapid expansion and development of both the public universities and public community colleges and of the pri-

Mr. Josey is Associate in Academic and Research Libraries in the New York State Education Department. vate universities, colleges, and professional schools, it was virtually impossible to provide for the research library needs of the growing numbers of students and faculty. There were 685,000 (full-time and part-time) students enrolled in colleges and universities in New York State during the 1967-68 academic year. It has been estimated that during the 197475 academic year, there will be 948,570 students enrolled in institutions of higher education in the Empire State. Essential to creative scholarship by undergraduates, graduate students, professors, and other researchers is quick and easy access to a growing mass of books, periodicals, monographs, and technical report literature. Thus, the avalanche of published scholarship from the publishers of the world is another great factor in the creation of the 3R's Systems.

Since New York is the country's leading manufacturing state, a vast amount of research and development is initiated there, which requires excellent library resources among its indispensable tools. With the ever-increasing demands for improved and expanded research library service, therefore, the Commissioner of Education appointed a select committee 
of twenty leading citizens in 1960 to study the library needs of the state's research community.

\section{Report of THE CoMmissioner's Committee}

After carefully studying the research needs of the state, the committee presented its findings and recommendations in 1961 in the Report of the Commissioner's Committee on Reference and Research Library Resources.

The report underscored the fact that "public library systems . . . cannot fully meet the special needs of research workers and professional people." It was emphasized also that public library systems cannot meet the library demands of college students. Supporting the contention that reference and research library resources systems would strengthen the public library systems were the following two goals as indicated in the report:

"Providing reader access to libraries over a larger area than that served by a single public library system.

"Providing reader access to other types of library collections-college, university, industrial research, and private special libraries."

\section{Nine Regional Systems}

Following the Governor's Conference on Libraries in 1965 and the first funding of the program in 1966, interest in the 3R's developed rapidly so that by May 31, 1967, the entire state had been organized into nine regional Reference and Research Library Resources Systems. Each of the nine regional systems is composed of a voluntary association of college and university, special, public, and research libraries. There are 133 academic institutions that are members of these systems.

\footnotetext{
${ }^{1}$ Report of the Commissioner's Committee on Reference and Research Library Resources. Albany: The University of the State of New York, The State Education Department, The New York State Library, 1961, p. 16.
}

\section{R's Funding and Projects}

As of this date the 3R's program is not funded by permanent legislation. Funds to support the program are appropriated to the State Education Department from the Governor's Executive Budget. The 1966 program was supported by a $\$ 700,000$ appropriation; the 1967 program received $\$ 850,000$; and the current fiscal year which commenced April $1, \$ 1,250,000$.

Statewide 3R's projects that have been developed to extend advanced reference and research library service have included the following:

1. an experiment in Facsimile Transmission designed to provide rapid access to research materials. This project commenced in January 1967 and terminated March 31, 1968. The program was abandoned because:

(a) the performance of the facsimile transmission equipment employed did not justify continuation,

(b) the poor quality of the copy limited the service, and

(c) there was not a high enough volume of demand to justify the cost;

2. an experiment in a statewide interlibrary loan project, known as NYSILL, which was inaugurated in March of 1967. The State Library has contracted with three large public libraries and nine private research libraries to provide access to their collections via interlibrary loan. These libraries are reimbursed by the state for lending their materials. Because of this innovative program, serious researchers are assured access to the rich private research collections in the state wherever they may be located in the state and whatever may be their affiliation; ${ }^{2}$

\footnotetext{
${ }^{2}$ For a more detailed discussion of the Facsimile Transmission Project and the New York State Interlibrary Loan Project see E. J. Josey, "Two 3R's Pilot Programs: NYSILL and FACTS," talk given at School/Public Library Relations Conference, Sheraton Motor Inn, New York City, February 8, 1968.
} 
3. several library electronic data processing projects. These include:

(a) the automation of the Serials Section of the State Library, and

(b) a system design for a general purpose computer-based catalog maintenance system for research libraries which has been completed by Theodore Stein Associates. This automated cataloging system may be used in the Mid-Manhattan Library of the New York Public Library. This library will serve undergraduate college students in the metropolitan New York City area. This design will be available to other research and college libraries in the state that wish to employ it;

4. plans currently underway for the publication of a statewide union list of serials. This list will contain the holdings of all of the major libraries in the state, and it will enable serious library users to identify, locate, and gain access to the enormous output of serial literature.

\section{Opinions of College Librarians Concerning the 3R Program}

In an effort to determine academic librarians' attitudes toward the 3R program, a questionnaire was sent to forty such persons who were actively involved in the 3R's as trustees of the systems or on committees and whose libraries were members of the 3R's regional systems. The questionnaire contained three questions. These forty college librarians are fairly representative in that they are affiliated with public and private institutions and represent a good cross section from all nine of the regional 3R's systems. The questionnaire was mailed on March 20 and the librarians were requested to return the document by April 15. By May 14, thirty, of 75 per cent, of those canvassed had responded. In view of the high percent- age of returns, the findings may be considered significant.

The first question consisted of two parts, and its overall objective was stated as follows:

As a college librarian, how do you view the role of the college library in the 3R's Program? If you do not view the college library's responsibility or role as being different from other libraries that are members of 3R's systems, is there a special contribution that the college library can make?

The response to question one is quite revealing. Five of the thirty respondents viewed the college library's role as being the same as other types of libraries; one of these five respondents, however, the librarian of the Albany College of Pharmacy, stated,

... I I don't view the college library's responsibility as being different from other libraries, but as librarian of a special college library (Pharmacy), I know that we can make a special contribution, since we do have materials in our subject specialty that other libraries would not have, and we are therefore a resource for anyone who needs these subjects.

A second member of this group, Barbara LaMont, Librarian of Vassar, said,

I do not see that the role of the college library is different in kind from that of other libraries. The extent of its contribution to the resources of the state or region will depend upon its strengths and weaknesses relative to other institutions. Of course that measure applies to other kinds of libraries as well.

An overwhelming number of respondents, 22 , or 73 per cent, believe that the college library's role or responsibility is different from other types of libraries that are members of the 3R's systems. Only three of the respondents did not answer the question.

On the philosophical side, since we are attempting to determine whether 
the role of the college library is different, and since the largest number of New York state college librarians who presented answers to the question declared their college libraries' roles to be different from those of other libraries, let us now listen to some of their comments.

Robert B. Palmer, Librarian, Barnard College, writes,

The role of a college library differs from that of a public library. Its main and primary responsibility is still service to the higher education institution of which it is a part, and not to the general public. As to the special contribution that a college library can make, a lot depends on the geographical location of the college library. If the college library is not located in or near a metropolitan area-it should offer liberal use of shared library facilities to other serious library users and researchers....

Mrs. Ottilie H. Rollins, Librarian of Clarkson College of Technology, indicates that ". . . Clarkson has definitely a different role to play than other libraries in the 3R's system. It should concentrate on the needs of the academic and research communities in the science and technology fields to facilitate the work of the researcher...."

Brother Thomas, Librarian of Iona College, writes that "in this program the college library is sort of a 'middleman." " Mary Campfield, Librarian of Ithaca College, views the college library's special contribution as providing "library service, whenever possible, to eligible patrons of public library systems both local and regional."

Two librarians who view their college libraries' role as being different underscore the fact that college libraries need help from other libraries. This viewpoint comes firstly from Mother O'Connor, Librarian of Manhattanville College who declares “ . . . yes, college libraries have a special need: access to more serious works of scholarship, long runs of periodicals . . . access to obscure univer- sity publications, etc., . . . " A second viewpoint in this same vein comes from Henry James, Librarian of Briarcliff College, who says,

. . . our role is essentially parasitic, and we look to the 3R's program to give our students access through Metro affiliates or neighboring libraries in the county to special monographs and journals. The big question for us is: what can we give in return? True we are providing increasing numbers of scholarly books . . . but is this enough? And how can we benefit our larger academic colleagues?

Two respondents clearly state that the college library's role is one of leadership in the 3R's systems. Edward A. Chapman, Librarian of Rensselaer Polytechnic Institute, suggests it should be

. . . almost one of leadership if funded to take on the extramural tasks entailed in network service, and to develop subjects to the depth required by the various regional interests to be served. The special contribution that the academic library can make lies in the nature of the requirements it is set up to serve-Reference and Research.

Supporting the leadership thesis is Donald Yelton, Librarian of the State University of New York College at Potsdam, who states,

It seems to me that the appropriate role of any library in the program is conditioned by its strength as a reference and research resource. In this perspective I would say that "pound for pound" (or volume for volume), the college library ... represents a stronger resource than the public library of equivalent size, since it contains a smaller proportion of ephemeral or merely "entertaining" works. In most situations a role of leadership seems indicated.

Time will not permit the reading of the comments of eight librarians who felt that while the college library's role is different, it possesses unique collections that could be made available to 
other academic libraries and to public libraries through interlibrary loan.

An appropriate conclusion to the catalog of responses to question one are the remarks of Egon Weiss, the Librarian of the United States Military Academy.

The academic library is destined to become the special resource center of specialized materials, e.g., Foreign Area Study, Technical Information, etc. Its major contribution to other libraries and systems, therefore, lies in its capability to render bibliographic services and access through electronic tie-ins with regional, state, and national networks and other pertinent data banks.

Question two was designed to ascertain from the college librarians the extent to which their libraries have profited by the ongoing 3R's program. The question was posed as follows:

Although the 3R's systems since 1966 have been financed out of an appropriation from the Executive Budget and unlike the public library systems are not financed as of this date with permanent legislation and permanent funding, certain statewide and regional projects have been undertaken. During this short span of time, what residual benefits have college libraries received from the $3 R$ 's program?

With regard to question two, eight of the thirty respondents listed three or more residual benefits from the 3R's programs. These benefits were listed as being the facsimile transmission experiment, and New York State interlibrary loan program, daily delivery service in the 3R's region, regional union list of serials, directory of resources, and a union catalog. Sixteen listed one tangible benefit; most frequently cited was the statewide interlibrary loan program. Three failed to respond, and only three indicated no tangible benefits had come to their libraries.

Basic to the benefits from the 3R's that the college librarians are citing as being serviceable to their libraries, and of equal importance, is their faith in the potential usefulness of the program for the future. This faith in the future is reflected in the following comments.

Emerson Jacob, Librarian of the State University of New York College at Fredonia, says " . . . we feel that the planning already undertaken will bring substantial gains in the future. If there is permanent funding, much greater regional library cooperation will be possible as certain plans and techniques already formulated become operational." The librarian of Finch College states "It is more of a promise of things to come and a faith in group effort that gives value to our participation in the program."

The net meaning of the replies to question two would appear to be that a large number of college librarians consider the one great intangible reward from the 3R's program to be the growth of cooperation among college librarians. They have demonstrated the feasibility and efficiency of concerted regional efforts in the councils. Evidence of this fact can be supported in these observations. Richard Shepherd, Librarian of the State University of New York College at New Paltz, writes, "The biggest accomplishment to date is the stimulation of interest and thinking about cooperation. The councils provide a vehicle for keeping the interest alive and putting projects to the test. Any activities that will relieve massive independent acquisitions programs and their local processing should be welcomed by libraries." Taisto J. Niemi, Librarian of LeMoyne College, states, "I think the best result has been that it has forced us to take a close, hard look at interlibrary cooperation ... the consensus now is not the fears of cooperation...."

Peter J. Laux, Librarian, Canisius College, concurs with this opinion in stating, 
Setting up regional centers has, I think, forced all of us to examine our mutual problems and think in terms of how we can best grow together rather than each of us going his separate way. I think that the greatest benefits lie ahead, but we have finally established a framework within which healthy cooperative development can take place. However, we do need better financial support.

If the program were terminated tomorrow there would, I think, be a legacy of interlibrary cooperation among regional libraries which should continue to be advantageous to colleges as well as to other libraries. Even without the machinery evolved by the Councils, the personal and professional relations should continue to bear fruit. All of us have increased our acquaintance with resources available in the region and in the State,

declared Donald Yelton of State University of New York at Potsdam.

The final question was, "What programs do you suggest that will benefit college libraries in the $3 R$ 's program?" This was answered by twenty-five, or 83 per cent of the respondents. Five failed to answer this question. The twenty-five respondents answering the question each suggested from one to four projects for the future. Thirteen suggested funds for cooperative acquisitions and shared use facilities; five indicated centralized processing; three called for storage facilities for lesser used materials; two pointed to the need for translation services; four desired a union catalog; four indicated need for an improved delivery service; one a repository for duplicate periodicals; nine desired a regional union list of serials; three suggested a more rapid efficient means of communications; four desired more continuing education workshops for staff of member libraries of the 3R's systems; four desired the installation of another facsimile transmission program; two suggested a regional reference center; three suggested the strengthening of the State Library in the areas of bibliography and foreign materials in order to strengthen its backstopping role; two listed computer support; and six indicated an improved interlibrary loan program. The programs that were suggested by the college librarians were merely a reflection of their 3R's regional goals, for most of the nine regional systems included most of these ideas as part of their budget proposals for the future. ${ }^{3}$ The listing of many of the same plans is evidence of the fact that college librarians are influencing the 3R's systems in planning for the future.

\section{College Libraries, the 3R's,} AND THE FUTURE

Data from this small sampling of college librarians reveal that they firmly believe that the role of the college library is different from other types of libraries. There is compelling evidence that they think that the college library has special roles to perform which include the uniqueness of its collections and its special resources that may be lent to serious research patrons of public libraries as well as providing leadership in the 3R's.

By and large, these college librarians represent a group that is strongly committed to interinstitutional library service in a network consisting of various types of libraries. Although most of them assume that college library collections are unique, they are willing to fit the college library into a viable plan for pooling and sharing of resources. Moreover, the large number that cited the compensated interlibrary loan program as helpful is proof that there is a keen awareness of the realities of the time that college libraries are no longer selfsufficient and must exploit the resources of other libraries. The librarians in the group were grateful for the opportunity to plug into regional and statewide resources, but they also are aware of the

${ }^{3}$ E. J. Josey, "Systems Development for Reference and Research Library Service in New York State: The 3R's" British Columbia Library Quarterly, XXXI (April 1968). 
importance of centralized indices which would identify and locate periodical and book holdings in order to expedite the transfer of materials between libraries.

While the data show that twenty-five of the thirty respondents indicated that their college libraries were aided by several ongoing 3R's projects as named above, it can reasonably be assumed that the involvement of the college librarians in their 3R's regional systems has, beyond a doubt, demonstrated conclusively the positive effects of regional and statewide planning.

College librarians in New York State may differ in the centrality of their concern for new 3R's programs for the future, as is recognized by the wide variety of programs envisioned or suggested. But, one fact is clear, i.e., a call has been sounded for regional development of library resources through cooperative acquisitions programs and for the pooling and use of shared resources and facilities.

Several of the librarians expressed the opinion that permanent funding continues to hold the solution to strengthening reference and research library service in the state. Most of this group of college librarians are pleased with the projects that have been inaugurated with 3R's funds; they nevertheless share the view of E. B. Nyquist, New York State Education Department's Deputy Commissioner, who contends that "the need for state legislation providing statu- tory state support for our state and regional programs, based on a formula reflecting need and use" ${ }^{4}$ must be implemented, if the 3R's systems are to face the challenge of meeting the advance reference and research library needs of the state.

A conclusion which is immediately apparent is that the college librarians involved in the $3 R$ 's program are endowed with the wisdom to predict that the interinstitutional system approach will not succeed unless the patrons of their libraries have the widest possible bibliographic and physical access to research library materials. Another hopeful conclusion, moreover, is that the experience and knowledge that college librarians have gained by working with a larger number of librarians from other types of libraries also have given them a deeper sense of participation in library affairs affecting a much larger area -the region-than their local community. This kind of cooperation bridges the gap between their own problems in college libraries and those in other types of libraries. Only through creative interinstitutional involvement can there be found creative solutions to pressing library problems. Finally, the eloquent testimony of this sampling of New York State college librarians can be interpreted as a total rejection of institutional competition in favor of interinstitutional cooperation.

"E. B. Nyquist, "The Three R's in New York," ALA Bulletin, LX (December 1966), 1138. 